von Hofe indicate a definite value in the method, which can be used with miotics. von Hofe found that calcium increased markedly the effect of adrenalin given subconjunctivally.

\title{
Summary
}

1. Adrenalin or glaukosan is of value especially in simple glaucoma, and by its means tension may be kept normal for considerable periods in certain cases.

2. Miotics should be used to prevent acute rise of tension when using adrenalin and to prolong its effect afterwards.

3. Amino-glaukosan presents the danger of increasing inflammation, and fails to reduce tension in many cases.

4. Hypertonic solutions can be depended upon to reduce tension before operation in acute glaucoma, and are without danger to the eye.

5. Ergotamine will reduce tension appreciably, it may be of much value in a small percentage of cases, and may be tried safely in any case.

6. All methods of treatment demand careful watch of the vision, fields and tension, so that progress of the disease may be noted early enough for effective surgical intervention.

\section{A CASE OF MONOCULAR BLINDNESS OF ELECTRICAL ORIGIN*}

\author{
BY \\ J. N. ROY \\ ASSOCIATE PROFESSOR AT THE UNIVERSITY OF MONTREAL \\ PHYSICIAN TO THE NOTRE-DAME HOSPITAL \\ LAUREATE OF THE ACADEMY OF MEDICINE OF PARIS
}

To my knowledge medical literature relates the observation of seven cases where the two eyes have been lost by the dazzling effect of electric light, after having been exposed to the intense luminous rays caused by lightning, by reverberation of the sun, and finally by a short circuit. As the patient-the subject of this work-has become blind of one eye only, after having been submitted, at a short distance, to the effects of electricity and of melting metal, I believe it interesting to publish his history, and will profit by this circumstance to recall the most recent theories on the injurious action of intense light in relation to the visual organ.

Case report.-On May 25, 1927, Mr. A. B., aged 37 years, labourer in a foundry, received the order to carry a bar of steel into an electrical soldering room. Entering these premises for

* Read before the 10th Congrès des Médecins de langue française de ''A mérique du Nord, Quebec, September, 1928. 
the first time, he was keenly impressed, especially by the description of the workings of the machinery by his companions. Also, at a distance of four to five feet from the luminous source, he looked with persistence, during a period of about eight minutes without any protective glasses, at the rays emitted by a mass of metal in a state of incandescence and disintegration under the action of a strong electrical current. During the hours which followed a double ophthalmia declared itself, and a few days later he noticed, a trouble and a weakness in the vision of the right eye. The palpebral and conjunctival objective symptoms of the two eyes disappeared rapidly, as they always do with the ordinary therapeutic treatment, but the visual power of the right eye diminished gradually. At the time of my examination, on January 15, 1928, I observed a cicatricial lesion of the retina, near the disc, on the temporal side, a lesion of the macula lutea, a narrowing of volume of the retinal arteries, and finally a generalised discolouration of the papilla, accompanied by a definite optic atrophy of this eye, which had reduced the vision to the point of luminous perception. The patient, being seen for the first time, it is impossible for me to describe the neuro-retinal alterations which have successively followed since the time of the accident. However, I have been able to know from the oculists who have observed him during the few months which have followed the dazzling, that on June 12 , that is to say 18 days after his exposure to the luminous rays, the vision of the right eye was $1 / 10$; on July 27 the vision was still $1 / 10$; on October $\tau$ a second oculist found it unchanged, and since that date the visual acuity had gradually diminished till it disappeared almost entirely.

As to the left eye, I have found that the condition was normal from all points of view.

Let us now rapidly see how light acts upon the eye. The action of light upon the visual organ may be shown under different aspects, but what is interesting for us to note is the effect that it produces on the retina. Daylight, as we know, is decomposed by the prism to a spectrum of which one part is visible; the two extremities, the infra-red and the ultra-violet, do not cause, in ordinary circumstances, a sensation of vision in the human eye.

We will then put aside the action of the ultra-violet and infra-red rays. Indeed, the first are nearly all absorbed by the middle parts of the eye which protect the retina; this is what seems to be the result of the numerous researches made on this question. The second would have especially some calorific properties more characteristic to it, but whose intensity upon the retina seems to be negligible. There remains, between these two extremities of the spectrum, the visible light which has not yet been absorbed by the middle parts, and which brings to the retina a luminous 
energy which this, after absorption, must transform into chemical, caloric and electrical effects, which will determine or accompany the visual sensation.

Whether light may be constituted according to the quantum theory, or by undulatory radiations, or by the two at the same time, in every hypothesis, it is necessary that it should be absorbed before acting and producing photo-chemical, photo-caloric, photoelectrical and photo-sensorial modifications on the retina.

These varied transformations of energy are not made without chemical or biological modifications of the retina, which are dependent on deep electronic modifications. Between certain limits, these modifications are reversible, beyond which they are destructive and permanent; the absorption which arranges them depends on the nature of the absorbert centres, on the wave length, and on the intensity of the incident radiations. Thus it is not astonishing that the radiations of a very intense visible light might produce serious and irreparable lesions of the retina by electronic modifications which give but very little heat.

The deeper study of the direct action of light upon the retina and, consecutively, upon the optic nerve, will help us later on to understand better some lesions and some biological phenomena that we are accustomed to associate with the effect of heat.

All that I have stated in relation to daylight naturally refers also to electrical or other lights. Consequently, it is easy to understand that if a visible luminous source of a weak or medium intensity does not produce any harmful action upon the retina, in other circumstances a powerful light can cause, on the fragile elements of this membrane, transient or permanent lesions which may sometimes terminate by complete atrophy of the optic nerve.

We know that electrical ophthalmia can produce, upon the skin of the face and of the eyelids, and on the anterior segment of the eye, especially by the effect of invisible ultra-violet chemical rays, and of invisible infra-red caloric rays, a series of changes including epidermitis, palpebral oedema, conjunctivitis, keratitis and iritis. I do not believe it necessary to insist more on this point, because these observations are admitted by all authors. However, I will recall that opinions are rather divided as to cataract of an actinic origin. A certain number of experimenters consider that the ultra-violet rays have the property of rendering the crystalline lens fluorescent, and that these invisible rays of a short wave length transform themselves into visible rays of a greater wave length. In admitting this hypothesis, it is easy to figure to ourselves that such a transformation of energy has the probable effect of modifying the crystalline body where the reaction is produced, and consequently that cataract is possible. Other observers are of opinion that it is the invisible infra-red radiations which are 
responsible, and that the lental opacity is dependent on these latter rays. It is needless to add that numerous laboratory experiments have been made upon animals before arriving at such assertions. And finally, a certain number of authors believe that neither the ultra-violet nor the infra-red rays can produce a cataract. However, it is a clinical fact of current observation-which I have myself noticed during my numerous travels in tropical countries, especially in Africa, in Oceania, in Central and South America, and particularly in Asia-that cataract is much more frequent in these latitudes than in countries where the sun is less powerful. Though, I believe that the very strong heat of these regions tends to modify the ocular nutrition, and that this phenomenon must be considered in discussing the aetiology of cataract. In the same order of ideas, I ask myself moreover, if the diet of the natives of these torrid zones, composed especially of fruits, vegetables and corn, must not also be considered.

As to the lesions of the deep layers of the eye observed following electrical dazzling, the retina is the membrane first affected. The macula lutea is particularly vulnerable to powerful luminous rays, and its alteration produces a central transient or permanent scotoma. The retina loses its transparency, and presents the aspect of a more or less oedematous cloud, surrounding the optic nerve and the large blood vessels. The papilla may remain normal; however, in certain circumstances it becomes inflamed, or simply "floue," and its borders appear lightly stippled. The visual acuity is diminished by alteration of the central vision, and sometimes the visual field is narrowed. In the majority of cases all these phenomena disappeared after a certain time, and the dazzling did not leave any trouble of the eye. In others, on the contrary, the papillo-macular bundle becomes atrophied, and this lesion produces a permanent central scotoma. And finally, when the light perceived has been intensive, it may result in cicatricial islets of the retina, a diminution of volume of its blood vessels, and finally a discolouration and an atrophy of the optic nerve, ending in blindness. Though these facts are not sufficiently discussed in the treatises of ophthalmology they are well known, especially by those oculists who have observed patients seriously affected by electrical ophthalmia.

I should like to recall the few rare cases published in the medical literature where amaurosis has ensued.

Brière gives the history of a young girl aged 11 years who, after having walked during a violent storm, on a road illuminated by flashes of lightning, presented ophthalmoscopical symptoms of a double neuro-retinitis, and finished by losing her eyesight.

Römer relates the case of a boy, aged $12 \frac{1}{2}$ years, who was overthrown by lightning which struck a tree at a distance of a 
few paces from him. The final result of the shock and the dazzling was a double papillary atrophy.

Knies also mentions a case of optic atrophy in a child, aged ${ }^{*} 10$ years, following electrical ophthalmia.

Brandenburg publishes the case of a patient who had a neuroretinitis followed by an optic atrophy after having worked outside all day long under an ardent sun.

And finally, Terrien, who has given special attention to this question, after having observed about fifty subjects during the construction of the Metropolitan Underground Railway of Paris, has seen atrophy of the optic nerve following electrical dazzling on three occasions.

In my patient, it is interesting to note that the deep layers of his left eye had not been hurt at the time of the accident, and that the vision of this eye was normal. However, it is natural to suppose and admit that when he was looking at the very strong light, a reflex movement had caused his head to turn towards the left side, and thus placed, the corresponding visual angle of this side presented less surface to the effects of the injurious visible rays upon the left retina, the pupil being protected by the nose.

In the present case, must we believe that the lesions of the retina, and consecutively the atrophy of the right optic nerve, have been produced by the electrical source itself, or by the visual light from the molten metal, or by these two kinds of radiations? It is rational to admit that all the incandescent particles had contributed to the ultimate effect : those that the electric arc had detached, as well as those which had remained adherent to the solid; but each one according to its temperature and its characteristic radiations. It is probable also that the rays had fallen slightly obliquely upon the face, and that the active luminous surface had not been very extensive, since the left eye had been protected by the nasal pyramid in a slight deviation of the head. To sum up, this case of monocular blindness of electrical origin-unique in medical literature-is very interesting.

\section{BIBLIOGRAPHY}

Brière.-Neuro-rétinites causés par la réverbération des éclairs. Cécité consécutive. Gaz. des Hôp., No. 41, 1876.

Netter.-Remarques sur une observation de cécité déterminée par des éclairs. Rev. Méd. de l'Est., p. 339, 1876.

Haab. - Sur les lésions oculaires dues à la lumière du soleil. Correspondenzbl.f. Schweizer Aertze, p. 383, 1882.

Gayet.-Sur le pouvoir absorbant du cristallin pour les rayons ultra-violets. Bull. Soc. Franc. d'Ophtal., 1884.

Little, D.-The effects of strong light upon the eye. Ophthal. Rev., July, 1884.

Vossius. - Sur les affectiones oculaires causées par la foudre. Centralbl. f. Prakt. Augenheilk., June, 1886.

Meyhoffer.-Ein weiterer Fall von Katarakt nach Blitzschlag. Klin. Monatsbl.f. Augenheilk., September, 1886. 
Martin.-Pathogénie des ophtalmies électriques. Ann. d'Ocul., July-August, 1887.

Terrier.-De l'ophtalmie électrique. Arch. d'Ophtal., p. 1, 1888.

Caudron.-Le coup de soleil électrique. Rev. gén. d'Ophtal., February, 1888.

Widmark.-De l'action de la lumière sur les milieux antérieurs de l'oeil. Skand. Arch., p. 264, 1889.

Bresse, A.-De l'ophtalmie électrique et du coup de soleil électrique. Thèse de Nancy, 1891

Nodier.-Sur une ophtalmie causée par la lumière électrique. Thèse de Nancy, 1891.

Vossius.-Ein Fall von Blitzaffection der Augen. Beitr. z. Augenheilk., p. 42, 1892.

Brose. - Two cases of electrical flashing followed by severe retinal irritation and intense pain. Arch. of Ophthal., p. 124, 1894.

Cassien. - Incidents produits sur l'appareil de la vision par l'électricité à bord des navires de guerre. Thèse de Bordeaux, 1895.

Rohmer - Des troubles produits par la fulguration sur l'appareil oculaire. Arch. d'Ophtal., p. 211, 1895.

Roy, Dunbar. - The effect of intense flashes of electric light upon the eye. Amer. Jl. of Ophthal., December, 1897.

Brandenburg.-Erkrankung des inneren Augenhaüte durch die Einwirkung grosser Sonnenhitze. Ein Betriebs unfall ? Aertzliche Sachverstandigen Zeitung, No. 2, 1899.

Preindelsberger.-Trois cas de cataracte par éblouissement. Wien. Klin. Wochenschr., p. 314, 1900.

Panas.-Amblyopie et amaurose par décharge électrique. Arch.d'Ophtal., p. 625 1902.

Terrien, F.-Du pronostic des troubles visuels d'origine électrique. Arch. d'Ophtal., p. 692, 1902.

Mettey, E.-Quelques recherches cliniques et expérimentales sur l'éblouissement électrique. Thèse de Paris, 1903.

Gonin.-Lésions oculaires causées par la foudre. Ann. d'Ocul., February, 1904.

Birch-Hirschfeld.-Sur l'action des rayons ultra-violets sur l'oeil. Arch. f. Ophtal., p. 469, 1904.

Rosenthal.-Des troubles oculaires surtout fonctionnels causées par la foudre. Thèse de Nancy, 1904.

Rohmer.-Accidents oculaires produits par l'électricité. Encycl.Franç. d'Ophtal., Tome IV, p. 825. 1905.

Ginestous.-L'ophtalmie électrique. Gaz. hebd. des Sci. Méd. de Bordeaux, December, 1906.

Birch-Hirschfeld. - Nouvelle contribution à l'étude des troubles oculaires causés par la lumière ultra-violette. Zeitschr. f. Augenheilk., July, 1908.

Gonin.-Ophtalmie des neiges. Ann. d'Ocul., September, 1908.

Terrien, F.-Cataracte par décharge électrique. Arch. d'Ophtal., November, 1908, Coullaud.-Huit cas d'ophtalmie électrique. Arch. d'Ophtal., January, 1909.

Dor, L.-Les rayons ultra-violets sont-ils nu sibles? Doit-on porter des verres jaunes ou des verres bleus? La Clin. Ophtal., September 10, 1909.

van Lint.-Accidents oculaires produits par l'électricité. Rapport à la Soc. belge d'Ophtal., November 28, 1909.

Hallauer.-Pouvoir d'absorption du cristallin. Klin. Monatsbl. f. Augenheilk., p. 721, 1909.

Best.-Sur les altérations de l'oeil par les rayons lumineux et ultra-violets. Klin. Monatsbl f. Augenheilk, March, 1910.

MacMullen.-Les effects nocifs de la forte lumière sur l'oeil. Ophthal. Rev., April, 1910.

Gariel. - Valeur comparative des divers modes d'éclairage. Rapport Cong. Soc. Franc. d.Ophtal., 1910.

Parsons, J. H. - Des effets de la vive lumière sur l'oeil. Jl. Amer. Med. Assoc., p. $2,027,19.10$.

Galli-Valerio, B.-Contribution à l'étude de l'ophtalmie des neiges. Ann.d'Ocul., March, 1911.

Berthelot, D.-Les effets chimiques des rayons ultra-violets. Rev. gén. des Sci., p. $322,1911$. 
Terrien, F.-Des troubles visuels provoqués par l'électricité. La Presse Med., March 6, 1912.

Vogt, A.-Recherches expérimentales sur la pénétrabilité des rayons infra-rouges à travers les milieus transparents de l'oeil. Arch.f. Ophtal., p. 155, 1912.

Gibbs, H. D.-Effets du soleil tropical sur l'homme et quelques animaux. Rev. gén. des Sci., p. 689, 1912.

Parsons, J. H.-Affections de l'oeil produites par l'exposition à la lumière excessive. Rapport Cong. Internat. de Méd. de Londres, Sect. d'Ophtal., August 6-12, 1913.

Moreau, F.-Ophtalmie électrique. Ann.d'Ocul., p. 351, 1916.

Roy, J. N.-De la vision chez les noirs de l'Afrique, Ann. d'Ocul., OctoberNovember, 1918.

Chappé.-Conjonctivite chez les artistes de cinéma. Ann. d'Ocul., July, 1920.

Roy, J. N.-Des affections oculaires dans la syphilis et la trypanosomiase humaine chez les indigènes de l'Afrique. Ann. d'Ocul., March, 1921.

Ginella.-Production de la cataracte par les infra-rouges. Arch. f. Ophthal., p. $483,1924$.

Müller, H.-Lésions oculaires par les rayons infra-rouges. Arch. f.Ophthal., p. 503, 1924.

Toulant, P.-Les rayons ultra-violets en ophtalmologie. Action sur le segment antérieur de l'oeil. Les Presses Univer. de France, Paris, 1926.

Roy, J. N.-L'éblouissement électrique. Quelques considérations médico-légales. Ann. d'Ocul., June, 1928.

\title{
HYPOPYON ULCER OF THE CORNEA DUE TO GLENOSPORA GRAPHII
}

\author{
BY \\ LT.-CoL. R. E. WRIGHT \\ PROFESSOR OF OPHTHALMOLOGY, MEDICAL COLLEGE, AND \\ SUPERINTENDENT, GOVERNMENT OPHTHALMIC HOSPITAL, MADRAS
}

N., a Hindu female, aged 38 years, presented herself on August 14, 1928 , with a hypopyon ulcer of the cornea. The lesion wais round, about $3 \mathrm{~mm}$. in diameter, situated in the centre of the inferior quadrant. An observer at first sight might have accepted the case as an ordinary ulcer with hypopyon, although there was a difference, which, without going into tedious detail, might be summed up by saying that the whole picture was more indolent than the usual hypopyon ulcer, using the word in its ordinary surgical sense. There was one feature, however, which could not have escaped the eye of an alert ophthalmologist: the floor of the ulcer was filled in by a tough slough, so that when one explored it with a suitably pointed piece of match wood soaked in pure carbolic, it was possible to demonstrate a slightly undermined edge, a gutter of demarcation, and a greyish yellow, and tightly adherent, central mass. After preliminary surgical cleaning of the conjunctival sac and superficial sterilisation of the slough, the latter was firmly seized in suitable forceps and removed with some difficulty. It was broken up in a sterilised Petri dish and cultures made at once on Sabouraud's medium. Under the microscope a dense mass showing an indistinct mycelium was observed, about which there was 